\title{
Dynamic Study on Landuse Based on RS Images in the Wohushan Region of Jinan
}

\author{
Fang Dong ${ }^{1, a^{*}}$ and Jianqiang $\mathrm{Xu}^{2, \mathrm{~b}}$ \\ ${ }^{1}$ School of Resources and Environment, University of Jinan, Jinan, China \\ ${ }^{2}$ College of Environmental Science and Engineering, Ocean University of China, Qingdao, China \\ a2008smilefang@163.com, b762102319@qq.com
}

Keywords: Land use; Remote sensing; Supervised classification; Change detection; Wohushan region of Jinan

\begin{abstract}
With the continuous urbanization, Land-use patterns are changing fast in the Wohushan region of Jinan. Four-phase RS images, including the TM data of 1987, 1996, 2006 and 2015 were selected to classify this area by using supervised classification of the maximum likelihood method. Detailed land-use types are collapsed into six categories, namely cultivated land, forest land, rural settlement land, water area, rage-grasses and road. Then the post-classification comparison method was used to monitor the change of land use dynamically in order to extract the change information from 1987 to 2015. Detailed analyses have revealed that great changes have taken place in the land use type of Jinan Wohushan region during 1987-2015. The area of agricultural land, forest land and rage-grasses decreased gradually which transformed into construction land. The agricultural land reduced $11.28 \mathrm{~km}^{2}$ and forest land reduced $7.72 \mathrm{~km}^{2}$. At the same time, the area of rural settlement land has been increasing during twenty-eight years, which was $12.66 \mathrm{~km}^{2}$ in 1987 has increased to $29.88 \mathrm{~km}^{2}$ by 2015 .The extent of road, which was $10.40 \mathrm{~km} 2$ in 1987 has increased to $13.17 \mathrm{~km}^{2}$ by 2015.Transfer matrix analysis have revealed that the cultivated land is the main source of other land use types. The increase in residential areas mainly comes from farmland, forestland and ragegrasses.
\end{abstract}

\section{Introduction}

Significant land-cover changes have occurred in response to human activities since the last century [1-3]. Conversion of cropland into residential areas has risen due to economic and population growth. For such a complex urban system, how to control its expansion rate timely and accurately has become an urgent problem. Because traditional investigation was time and labor consuming, it was necessary to extract the landuse information based on remote sensing image [4-6]. Many scholars have done a lot of research on city expansion using RS and achieved good results [79]. RS and GIS tools were used to assess changes in land-use/land-cover patterns [10, 11] and valuable information was gained for analysis of effects of climate change and environmental impacts of human activities. Wohushan region of Jinan is the important groundwater supplying region. The landuse changes will significantly affect the ecological environment of the region. The main aim of this study was to determine land use changes in this region using multitemporal Landsat data for the period of 1987-2015.

\section{Study Area}

Wohushan region is located in the southern part of Jinan city, which belongs to northern mountains of Mount Tai. The total area is about $629 \mathrm{~km}^{2}$. It stretches from latitudes $36^{\circ} 20^{\prime} \mathrm{N}$ to $36^{\circ} 37^{\prime} \mathrm{N}$ and from longitudes $116^{\circ} 56^{\prime} \mathrm{E}$ to $117^{\circ} 21^{\prime} \mathrm{E}$. Climate is mainland monsoon-type. The terrain of Wohushan region slopes downwards from the south to the north. The study area is not only the natural eco-defence of the whole city but also the groundwater supplying region. 


\section{Data}

Four phases of remote sensing data were used in this paper: May 4, 1987; October 11, 1996; May 2, 2006; June 12, 2015 (path and row of 122/035). The data used for reference mainly include the detailed topographic map (1:50,000) and land use map (1:20,000).

\section{Method}

Image Preprocessing. In this study, radiometric correction of all period's images had already been done and the geometric distortion for the image of 1996 had been rectified. So the image of 1996 was used to perform image-to-image rectification for the images of 1987, 2006 and 2015 by using the bilinear resampling method. The RMSE between each two images was less than 0.5 pixel using at least 30 GCPs.

Resize Data. Wohushan region boundary was obtained by the digital topographic map and the mask was built. When the mask was applied to the TM image, the remote sensing images for research were generated (Fig. 1).

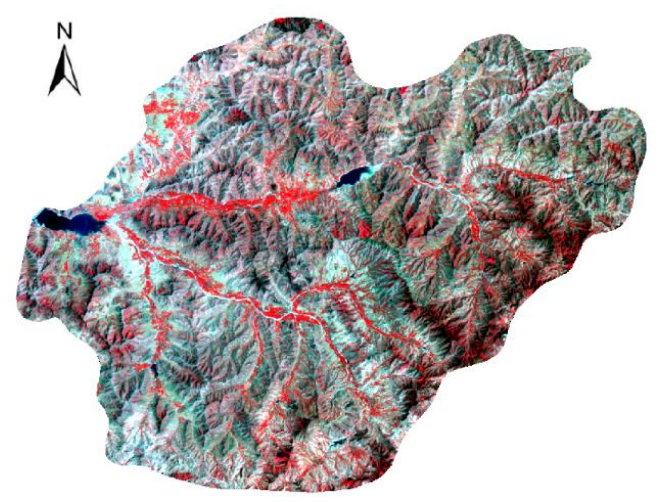

(a)

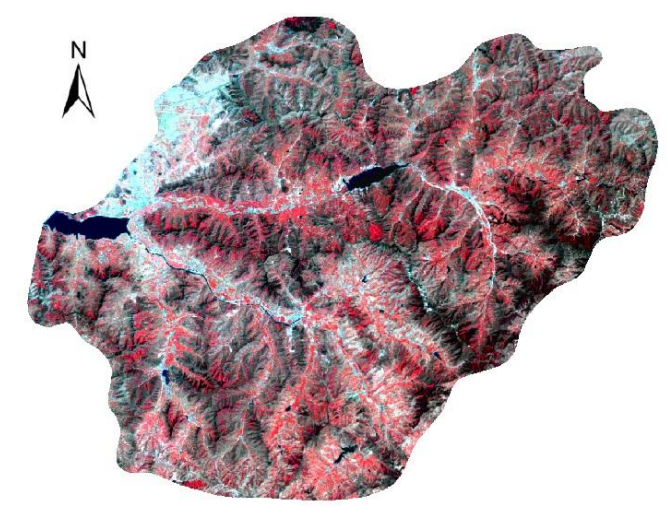

(c)

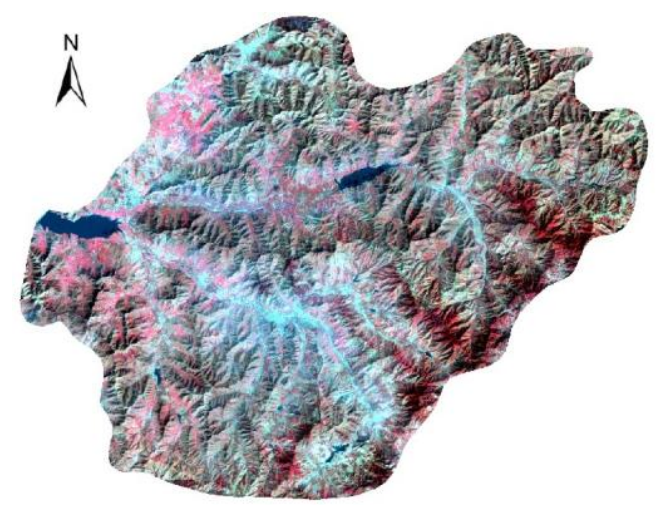

(b)

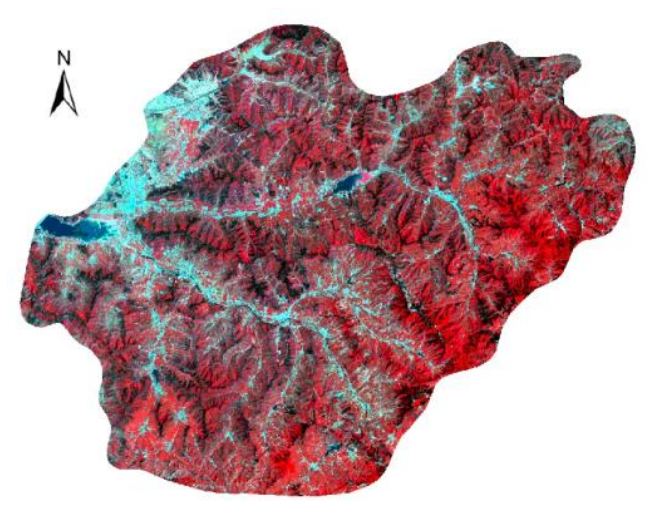

(d)

Figure 1. TM image of the Wohushan region

((a) TM image in 1987; (b) TM image in 1996; (c) TM image in 2006; (d) TM image in 2015)

Image Classification. In accordance with the 2007 National Land-use Classification Standard, namely cultivated land, forest land, rural settlement land, water area, rage-grasses and road. Remote sensing data of four dates were independently classified using the supervised classification method of maximum likelihood algorithm. Firstly, regions of interest (ROI) for six types were located in the remote sensing data. Secondly, the regions of interest were purified by using the n-D Visu alizer, which the ROI Separability was greater than or equal to 2.0. After purification, classification signature files were created and used by maximum likelihood classifier to automatically categorize every pixel in the entire image into the land use class. Then Wohushan region landscape type maps covering different periods were subsequently obtained (Fig. 2). 


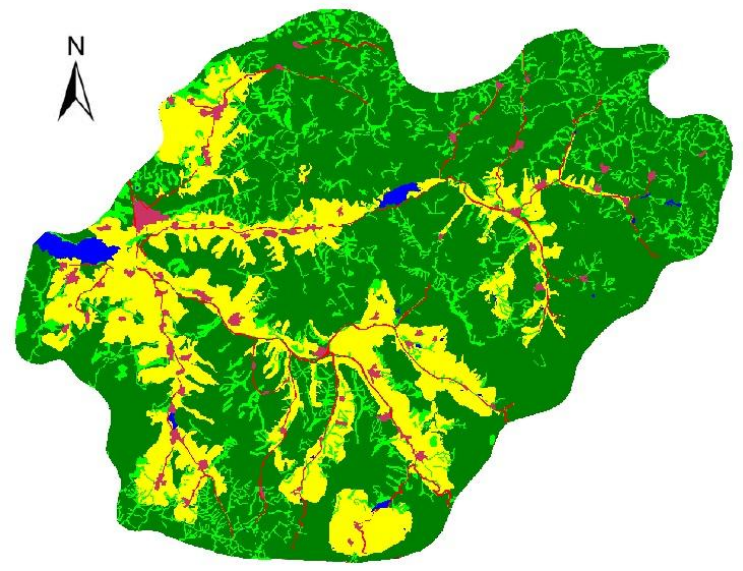

(a)

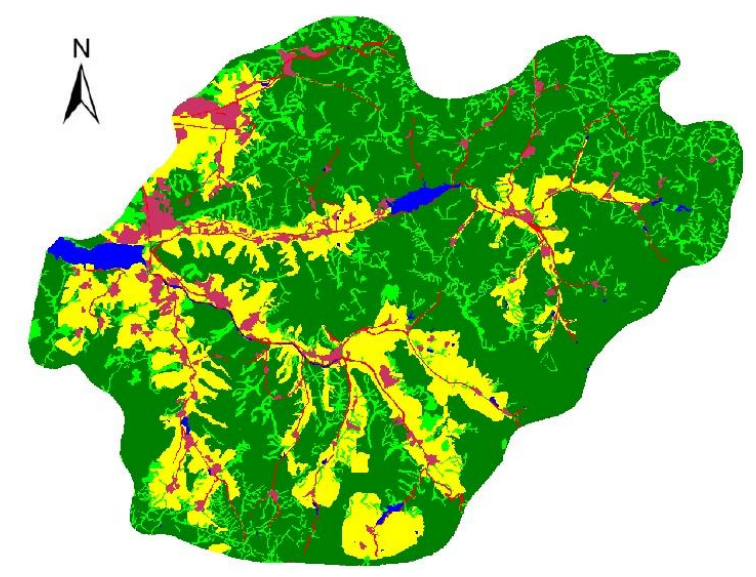

(c)

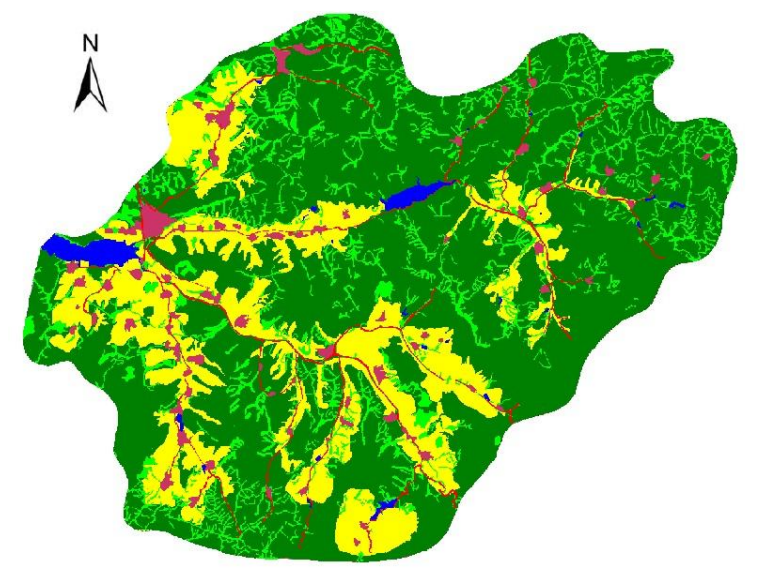

(b)

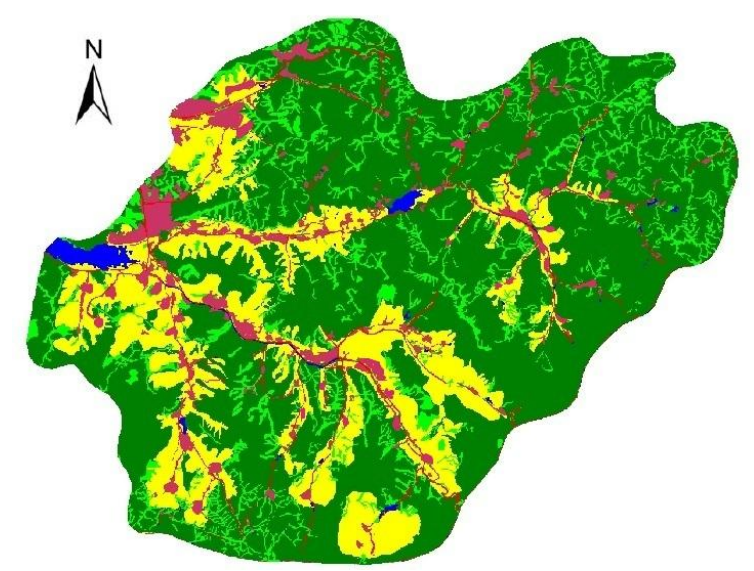

(d)

\section{Legend}

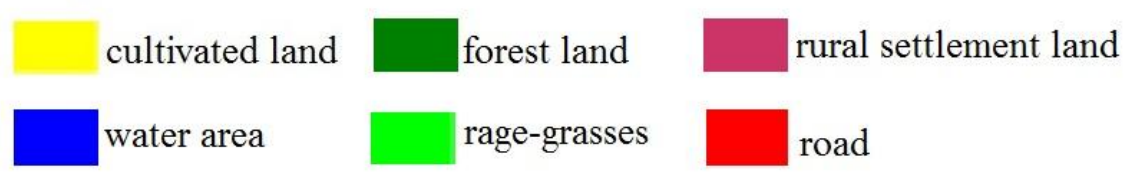

Figure 2. Land use distribution of the Wohushan region

((a) land use distribution in 1987; (b) land use distribution in 1996;

(c) land use distribution in 2006; (d) land use distribution in 2015)

\section{Results and Analyses}

In this study, the quantitative and spatial change information in the Wohushan region from 1987 to 2015 were analyzed by using the Geographic Information System (GIS).

Change Detection. The date of remote sensing image is different, so a multidate postclassification comparison change detection method was used to monitor the change of land use in three intervals, namely, 1987-1996, 1996-2006 and 2006-2015. The area and area changed of the six land use classes during the two intervals are shown in Table 1.

(1) Cultivated land: Table 1 showed that cultivated land decreased continuously in the whole monitoring period. The area of agriculture has decreased from $21.83 \%$ to about $19.88 \%$ during the period 1987-2015. There was a great decrease during the period 1987-1996, but slighter decrease was observed during 1996-2015. From 1987 to 1996, the area of agriculture has declined from $21.83 \%$ of the entire area to $20.17 \%$, a reduction of $10.40 \mathrm{~km}^{2}$. 
(2) Forest land: there were no significant changes in forest area. The area was about $62.25 \%$ in 1987, which has decreased to 62.22\% and 60.89\% in 1996 and 2006, respectively. And a slight increase was observed during 2006-2015.

Table 1 Results of land use classification and area change for 1987, 1996, 2006 and $2015\left[\mathrm{~km}^{2}\right]$

\begin{tabular}{cccccccc}
\hline \multirow{2}{*}{ Class name } & \multicolumn{3}{c}{ Area } & \multicolumn{4}{c}{ Area changed } \\
\cline { 2 - 8 } & 1987 & 1996 & 2006 & 2015 & $1987-1996$ & $1996-2006$ & $2006-2015$ \\
\hline cultivated land & 137.48 & 127.08 & 126.01 & 125.20 & -10.40 & -1.07 & -0.81 \\
forest land & 392.14 & 391.98 & 383.54 & 384.42 & -0.18 & -8.45 & 0.88 \\
\hline rural settlement & 12.66 & 17.21 & 27.61 & 30.88 & 4.55 & 10.40 & 3.27 \\
$\quad$ land & 5.70 & 8.39 & 9.12 & 6.85 & 2.69 & 0.73 & -2.27 \\
water area & 71.53 & 74.54 & 70.56 & 69.39 & 3.01 & -3.98 & -1.17 \\
rage-grasses & 10.40 & 10.71 & 13.07 & 13.17 & 0.31 & 2.36 & 0.10 \\
road & & & & & & & \\
\hline
\end{tabular}

(3) Rural settlement land: construction land has increased from $12.66 \mathrm{~km}^{2}$ to $30.88 \mathrm{~km}^{2}$ from 1987 to 2015 for the study area. The data showed that the building areas occupied $2 \%$ of the total area in 1987, 2.73\% in 1996, 4.38\% in 2006 and $4.90 \%$ in 2015.

(4) Water: the area of water changed little. The water areas occupied $0.9 \%$ of the total area in $1987,1.33 \%$ in $1996,1.45 \%$ in 2006 and $1.09 \%$ in 2015. Area of it increased before 2006, and then declined slightly. Water lost $2.27 \mathrm{~km}^{2}$ of its 2006 area by 2015, with the narrowing of rivers, disappearance of many ponds and little lakes throughout the study area.

(5) Rage-grasses: the area of rage-grasses decreased slightly year by year, from $71.53 \mathrm{~km}^{2}$ to $69.39 \mathrm{~km}^{2}$ during the period $1987-2015$.

(6) Road: the area of road increased continuously in the whole monitoring period. Area was about $10.40 \mathrm{~km} 2$ in 1987 , which was increased to $10.71 \mathrm{~km} 2$ by $1996,13.07 \mathrm{~km} 2$ by 2006 and further increased to $13.17 \mathrm{~km} 2$ by 2015 .

Land Conversion Matrix Analysis. To further evaluate the transfer of different land use types, we calculate the Markov transition matrices of land-use conversion for the three periods of 1987 1996, 1996 - 2006, and 2006 - 2015 (Table 2-4).Transfer between rural settlement land, cultivated land and forest land was the main land use change type in period between 1987 and 2015.

Table 2 Matrices of land use changes from 1987 to $1996\left[\mathrm{KM}^{2}\right]$

\begin{tabular}{ccccccc}
\hline 1987 land uses & \multicolumn{7}{c}{ 1996 land uses } \\
\cline { 2 - 7 } & rage-grasses & road & $\begin{array}{c}\text { cultivated } \\
\text { land }\end{array}$ & $\begin{array}{c}\text { rural settlement } \\
\text { land }\end{array}$ & forest land & water \\
\hline $\begin{array}{c}\text { rage-grasses } \\
\text { road }\end{array}$ & 71.22 & 0.02 & 0.02 & 0.16 & 0.03 & 0.09 \\
$\begin{array}{c}\text { cultivated land } \\
\text { rural settlement }\end{array}$ & 0.02 & 10.16 & 0.08 & 0.07 & 0.04 & 0.03 \\
$\quad$ land & 0.07 & 0.31 & 126.38 & 3.55 & 3.25 & 1.92 \\
forest land & 0.95 & 0.16 & 0.29 & 1.43 & 388.58 & 0.72 \\
$\quad$ water & 0.01 & 0.01 & 0.02 & 0 & 0.06 & 5.60 \\
\hline
\end{tabular}


Table 3 Matrices of land use changes from 1996 to 2006[KMㄹ $]$

\begin{tabular}{ccccccc}
\hline 1996 land uses & \multicolumn{7}{c}{ 2006 land uses } \\
\cline { 2 - 7 } & rage-grasses & road & $\begin{array}{c}\text { cultivated } \\
\text { land }\end{array}$ & $\begin{array}{c}\text { rural settlement } \\
\text { land }\end{array}$ & forest land & water \\
\hline $\begin{array}{c}\text { rage-grasses } \\
\text { road }\end{array}$ & 70.25 & 0.64 & 0.78 & 2.67 & 0.05 & 0.15 \\
$\begin{array}{c}\text { cultivated land } \\
\text { rural settlement }\end{array}$ & 0.02 & 9.41 & 0.19 & 0.42 & 0.17 & 0.50 \\
$\quad$ land & 0.05 & 1.58 & 118.18 & 7.00 & 0.01 & 0.26 \\
forest land & 0.09 & 0.19 & 1.44 & 15.13 & 0.35 & 0.03 \\
water & 0.07 & 0.02 & 0.09 & 0.05 & 0.17 & 7.97 \\
\hline
\end{tabular}

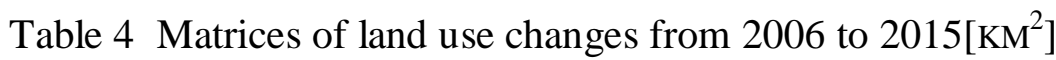

\begin{tabular}{ccccccc}
\hline 2006 land uses & \multicolumn{7}{c}{ 2015 land uses } \\
\cline { 2 - 7 } & rage-grasses & road & $\begin{array}{c}\text { cultivated } \\
\text { land }\end{array}$ & $\begin{array}{c}\text { rural settlement } \\
\text { land }\end{array}$ & forest land & water \\
\hline $\begin{array}{c}\text { rage-grasses } \\
\text { road }\end{array}$ & 67.17 & 0.37 & 0.92 & 1.69 & 0.40 & 0.06 \\
$\begin{array}{c}\text { cultivated land } \\
\text { rural settlement }\end{array}$ & 0.37 & 9.72 & 1.11 & 0.87 & 0.87 & 0.22 \\
$\quad$ land & 0.24 & 1.08 & 110.12 & 5.02 & 5.21 & 0.10 \\
forest land & 1.24 & 0.71 & 3.90 & 23.42 & 2.22 & 0.06 \\
water & 0.13 & 1.07 & 3.65 & 3.57 & 374.96 & 0.19 \\
\hline
\end{tabular}

Table 3-4 indicated that $3.55 \mathrm{~km}^{2}, 7.00 \mathrm{~km}^{2}$ and $5.02 \mathrm{~km}^{2}$ agriculture areas were conversed to construction land, around $2.50 \%, 7.00 \%$ and $4.13 \%$ of total agricultural conversion area, from 1987 to 1996, from 1996 to 2006 and from 2006 to 2015, respectively. Increases in construction land mainly came from conversion of agriculture and forest land to construction land. Of the $18.22 \mathrm{~km}^{2}$ of net total growth in construction land use from 1987 to 1996, 54.56\% was converted from agriculture and $25.85 \%$ from forest land. Water areas in the period mainly lost to forest and agriculture. The increases in road from 1987 to 2015 mainly came from conversion of agriculture and forest land to road.

\section{Conclusions}

In this study, the land use changes were monitored by using TM image from 1987 to 2015 . There were great spatial differences of land use change in Wohushan region of Jinan. It was evident that agricultural and forest land was reduced while construction area increased. The increasing trend of construction land could be attributed to rapid increase of rural population and urban economic.

\section{Acknowledgements}

This paper is derived from the social science fund of University of Jinan : X1146. 


\section{References}

[1] Turner II, B.L., William, B.M., Ross R.H.and Skole, D.L: J. Ambio. Vol.23 (1994), p.91.

[2] Misrak, A., Suryabhagavan, K.V.and Balakrishnan, M: Int. J. Ecol. Environ. Sci, Vol.38(2012), p.39

[3] A. Y. Kwarteng and P. S. Chavez Jr: International Journal of Remote Sensing, Vol.19 (1999), p.1651

[4] Belay, T.: Ethiopia. East. Afr. Soc. Sci. Res. Rev, Vol. 18(2002), p.1.

[5] Moller-Jensen L: Object Models and Texture, Vol. 3(1997), p. 174.

[6] Alberti M, Weeks R, and Coe S: Photogr Eng Remote Sens., Vol. 70(2004), p.1043.

[7] Ziyong Sun, Rui Ma, and Yanxin Wang: China, Environ Geol, Vol. 57(2009), p.1825.

[8] Liu Jiyuan: China science and technology press (Beijing, 1996) (In Chineses).

[9] Gebresamuel, G., Singh, B.R and Dick, O: Section B Plant Soil Sci, Vol.60 (2010), p. 211.

[10] Jinfeng Dua, Jean-Claude Thill, Richard B. Peiserc and Changchun Fengd: Landscape and Urban Planning, Vol.124 (2014), p.118.

[11] Shegena Zewdu, K.V. Suryabhagavan and M. Balakrishnan: Journal of the Saudi Society of Agricultural Sciences, Vol. 15 (2016), p. 91 - 97. 